\title{
The Rise of Fund Managers in Foreign Exchange: Will Fundamentals Ultimately Dominate?
}

\author{
Thomas Gehrig, University of Freiburg, Germany, and CEPR, London \\ and \\ Lukas Menkhoff, University of Hannover, Germany
}
Discussion paper No. 308
November 2004
ISSN 0949-9962

\begin{abstract}
:
This paper analyzes the behaviour and motivation of fund managers in foreign exchange markets reflected in questionnaire evidence. We find that fund managers and FX dealers differ significantly. Fund managers rely more on fundamentals, basically due to their longer forecasting horizons, and reject non-fundamental influences on exchange rates more than FX dealers. However, neither can fund managers be considered as pure fundamentalists. Non-fundamentalist positions markedly influence short-term decision-making. They inspire ambivalent views about market imperfections and these views seem to become stronger over time. This latter change counterbalances the strengthening fundamental influences resulting from the rise of fund managers.
\end{abstract}

JEL-Classification: F31, G23

Keywords:

foreign exchange, market microstructure, fund management, fundamentals

corresponding: Lukas Menkhoff, Department of Economics, University of Hannover, Königsworther Platz 1, D-30167 Hannover, Germany, menkhoff@gif.uni-hannover.de 


\section{The Rise of Fund Managers in Foreign Exchange:}

\section{Will Fundamentals Ultimately Dominate?}

\section{Introduction}

International fund managers seem to increasingly dominate foreign exchange markets. Although they do not match FX dealers in terms of turnover, they do outweigh them when it comes to holding positions. Whereas FX dealers usually close positions on a daily basis, international fund managers typically hold positions over longer periods of time. Therefore, one might expect that fund managers tend to be closer to the fundamentalist role-model. Are foreign exchange markets therefore increasingly driven by fundamentalist strategies? This is the basic question of our paper.

This study is the first to analyze the differences between groups of market participants by means of survey evidence, based on questionnaires sent out to both international fund managers and FX dealers. The emerging picture of a major change in foreign exchange due to the rise of fund managers - that are more fundamentally oriented than FX dealers - is restricted in two ways, however: first, the fundamental stance of fund managers is weak when assessed from an absolute point of view.

Second, fund managers' behaviour has changed over time. The underlying survey is the only one in foreign exchange that can be directly compared with an older questionnaire survey. We find that fund managers behave increasingly more like conventional FX dealers, i.e. they increasingly show a preference for non-fundamental behaviour. Thus, foreign exchange markets will stay imperfect, being influenced by 
influenced by individual rationality and behavioural elements that do not always bring about efficient markets.

The motivation for this research stems from the elementary macroeconomic question about the determinants of exchange rates. This issue is of particular importance since traditional economic models fail consistently in the shorter-term (Frankel and Rose, 1995; Taylor, 1995; De Grauwe, 2000). ${ }^{1}$ As direct empirical information about trading portfolios is not easily available ${ }^{2}$, one alternative way to learn about the real behaviour of market participants, their institutional constraints and ways of thinking is by asking them directly by means of questionnaires. This research has so far concentrated on FX dealers. However, this focus may yield seriously biased or distorted results since, as Goodhart (1988) notes, FX dealers mostly trade on very short-term notions and avoid taking larger open positions. Thus they may not be the natural candidates to move exchange rates beyond the very short-term horizon.

According to the order flow approach, advanced by Evans and Lyons (2002), FX dealers predominantly perform the function of intermediaries who mainly redistribute incoming customer orders. According to this view, customer orders have the largest impact on exchange rates. Whereas companies conducting international trade used to be the major customers in the past, the last decade has witnessed the rise of fund managers and their lead on the foreign exchange market (see Table 1). Recent research indeed indicates that it is in particular this latter group whose net orders are closely related to shorter-term exchange rate changes (see Lyons, 2001; Carpenter and Wang, 2003; Mende, Menkhoff and Osler, 2004). Therefore, a mean-

\footnotetext{
${ }^{1}$ The failure of traditional exchange rate models is of elementary importance for related policy issues, such as the suitability of exchange rates as nominal anchors (Willett, 1998), the justification of national currencies (Cooper, 1999) or the choice and design of exchange rate regimes in general (e.g. Tavlas, 2003).

${ }^{2}$ Chevalier and Ellison (1997) is the first empirical study of real trading portfolios combining information on the fund managers with trading data.
} 
ingful explanation of exchange rate movements should profit from considering the behaviour of international fund managers. How do they trade in FX markets?

This survey study intends to fill this gap by questioning international fund managers and comparing their response with that of FX dealers. ${ }^{3}$ We provide a comprehensive picture of the behaviour and motivations of fund managers and we relate findings to the broader literature on market imperfections and behavioural finance. Results show that fund managers act on much longer forecasting horizons and rely much more on fundamentals than FX dealers. However, they cannot generally be considered as fundamentalists. This is particularly true for short-term decisions. Their views about market imperfections are ambiguous, even though our data indicate that they reject non-fundamental influences on average more than FX dealers. A similar result holds for the preferred sources of information of fund managers and FX dealers. The examined elements of behaviour, views and sources of information provide a clear contrast between fund managers and FX dealers and they are in particular more different than for fundamentalists versus non-fundamentalists.

Surprisingly, by comparing the recent survey with an earlier 1992 survey, we find that fund managers turn to behave more like FX dealers over time and that both groups tend to behave in a more non-fundamental way. Thus a clear answer emerges regarding our research question about the future role of fundamentals in foreign exchange: while the influence of fund managers increases, they increasingly behave like FX dealers. This evidence does not really symbolize a new era in exchange rate behaviour. More research on fund managers' behaviour is thus called for.

\footnotetext{
${ }^{3}$ Survey studies have been introduced as an empirical instrument into financial economics by Shiller (1989), who has consistently worked with this instrument since (see e.g. Shiller, Kon-Ya and Tsutsui, 1996; see also Strong and Xu, 2003). The method has also gained
} 
The paper is organized in the following way. Section 2 briefly reviews relevant literature to craft appropriate hypotheses on the behaviour of fund managers in foreign exchange markets. A core element in this respect is the difference between the group of fund managers and the group of FX dealers. Section 3 describes the data and methodology of the survey. Section 4 contains the analyses that directly test the hypotheses on behaviour and the differences to dealers. Another group of analyses in Section 5 aims at testing the robustness of this information, in particular by providing indications about possible changes over time. Section 6 provides concluding remarks, incorporating policy aspects.

\section{Literature and hypotheses}

Our understanding of foreign exchange markets is still quite incomplete, as there is no model which could reliably explain shorter-term exchange rate movements on the basis of economic fundamentals. This does not mean, however, that fundamentals do not play any role. First, fundamental news influences the course of exchange rates as many event studies have shown in the past (see survey in Sarno and Taylor, 2002). Second, there is an impact of fundamentals in the long run, as demonstrated in particular by the literature on purchasing power parity (e.g. Rogoff, 1996). Third, there is also some non-linear relation between fundamentals and exchange rates in the shorter run (e.g. MacDonald, 1999; Clarida et al., 2003). Despite these advances, there is no model for generally capturing exchange rate behaviour in-sample, not to speak of out-of-sample modelling (see recently, Neely and Sarno, 2002). Thus exchange rates appear to be influenced by forces so far unknown. This situation has greatly stimulated microstructure research in foreign exchange. 
Goodhart (1988) suggests that the conventional understanding of FX participants may be misleading, since FX dealers do not behave as long-term oriented fundamentalists. Five stylized facts stand out from his intensive interviews with London bankers (all citations are from p.457; emphasis is in the original): first, their trading is an "extremely large-scale, very short-term speculative activity". Second, this trading is "not based on a long-term future view of economic fundamentals". Third, they "insist on closing out loss-making positions quickly, whatever the economic fundamentals may indicate". Fourth, "the bank itself may take a view on future currency movements that is more related to longer-term economic fundamentals". Fifth, "the size of banks' open positions is quite a small, often a very small, proportion of their capital". In essence, banks do not behave as long-term position takers, as the overwhelming amount of their trading is of a very short-term nature, i.e. in the intra-day range. Moreover, fundamentals are only of a very limited importance for most decisionmaking.

The limited importance of FX dealers for exchange rate movements beyond intra-day concerns has been indirectly addressed by microstructure research analyzing dealers' behaviour. Lyons (1995) is the first study supporting Goodhart's notion that FX dealers do not hold large open positions, by providing deal-by-deal evidence on the behaviour of a large FX dealer. Available studies unanimously show very limited position taking and a clearly risk-adverse trading pattern (see Mende, Menkhoff and Osler, 2004). Consequently, the importance of FX dealers on the course of exchange rates seems to have been overestimated in the past.

Studies based on survey questionnaires have extended Goodhart's notions in several respects. Particular attention has been paid to the different kinds of information types used by FX dealers. Taking up Frankel and Froot's (1990) concern of fun- 
damentalists and chartists, Taylor and Allen (1992) provide the first systematic survey evidence on the use of technical analysis in foreign exchange. Their finding of a relatively stronger relevance of fundamentals at longer horizons only has been confirmed by Gehrig and Menkhoff (2003), among others. Recently, the relevance of a third independent instrument, "order flow analysis", in addition to fundamentals and charts, has been documented e.g. for the UK (Cheung, Chinn and Marsh, 2000).

In contrast to FX dealers, the average fund manager operates on considerably longer time horizons. The typical horizon is on the order of months rather than days. Individual fund managers are widely rewarded according to their performance in a period of three to six months. So, there is no doubt that fund management is clearly of a longer-term orientation than FX dealing. This might motivate fund managers to employ more fundamental considerations. Moreover, since they are under less time pressure, they can afford to collect and synthesize fundamental information more readily than FX dealers, who are mainly concerned to close positions within minutes or hours. Earlier research indeed indicates that the behaviour of fund managers is more in line with that of a rational investor as regards horizon and the use of fundamental information (Gehrig and Menkhoff, 2003).

On the other hand, also fund managers' decisions are subject to limitations. In particular, recent research has identified two kinds of limitations: rational anticipations towards imperfect markets and behavioural biases (in otherwise perfect markets). Regarding the rational behaviour three distinct mechanisms are discussed in the literature. First, rationality of fund managers has to be judged relative to the compensation schemes they are subjected to. Chevalier and Ellison (1997), for example, have documented how compensation packages may affect risk-taking by fund managers. Moreover, Dow and Gorton (1997) provide a theoretical explanation of how market 
incentives can generate churning rather than information production among fund managers. Second, information costs may be so high for fund managers that they resort to cheaper "short-cuts" which means basically to rely on related information which is available and expected to be reliable. This leads to coordinated behaviour on questionable information (see Calvo and Mendoza, 2000). Third, coordinated behaviour may be the outcome of so-called rational herding (Bikhchandani and Sharma, 2001). Then fund managers neglect their own private information and rely on the revealed information of others, instead (see Sias, 2004). A possible consequence of such a kind of investment behaviour may be reliance on the popular and profitable momentum strategies (Griffin, Ji and Martin, 2003).

Another line of recent research indicating limitations to perfect markets is the behavioural finance approach. It examines behavioural elements in decision making that lead to deviations from traditional understanding of perfectly rational behaviour (surveys e.g. in Shleifer, 2000; Shefrin, 2002). The underlying theme is the importance of psychology in real world decision-making. A very robust and relevant phenomenon in this respect is the "anchoring" effect, relating the forming of estimates to an initial value, such as inherent in the actual investment position taken (see also Kahneman, Knetsch and Thaler, 1991). Another such phenomenon is "belief perseverance", i.e. the observation "that once people have formed an opinion, they cling to it too tightly and for too long" (Barberis and Thaler, 2003). In both cases, the incorporation of news into asset prices will typically be delayed.

Therefore, it is important to ask how closely fund managers behave relative to the prototype of a "perfect" fundamentalist. It is known that FX dealers do not base their short-term decisions on fundamental analyses (see Taylor and Allen, 1992), but 
fund managers could do so as they typically apply longer horizons. This leads to hypothesis 1:

H1 At any forecasting horizon fund managers resort more to fundamental analysis than FX dealers.

What kind of view of market imperfections could be expected from a more fundamentally oriented foreign exchange professional? In general, a person relying on fundamentals behaves consistently if that person believes that foreign exchange is, by and large, driven by fundamentals. This implies that other influences of a nonfundamental nature should not be regarded as very important, such as reliance on technical analysis (in order to mimic the behaviour of others and thus to herd) or the price influence of big market participants. Also behavioural finance elements are expected to be less important for fund managers, such as psychological price impacts or distortions in decision making by own positions taken. Finally, comparatively efficient markets should process information quickly. When it comes to the sources of information preferred, fund managers are expected to emphasize truly fundamental sources more than FX dealers. Overall, such a fundamentalist-like stance by equity fund managers has been found in relation to private investors (Shiller and Pound, 1989).

H2 Fund managers hold more fundamentalist-like views on market imperfections than FX dealers.

H3 Fund managers tend to use fundamental sources of information more than FX dealers.

To further substantiate the differentiation between fund managers and FX dealers, we investigate whether this distinction is crucial. In light of earlier findings, the question is not whether there are any marked differences between both groups, but 
whether these differences are more important than others, in particular the often preferred distinction between fundamentalists and non-fundamentalists, such as chartists (see e.g. Frankel and Froot, 1990).

H4 When examining characteristics of behaviour, views and sources of information, the distinction between fund managers and FX dealers discriminates better than the one between fundamentalists and chartists.

As a final test of the robustness of our findings, we investigate whether the structure of findings for the year 2001 changes relative to the 1992 data. Under the hypothesis that compensation schemes for fund managers did not change, one might conjecture that their behaviour also did not change.

H5 Findings for the year 2001 are similar to those for the year 1992, and the findings for both fund managers and FX dealers do not change systematically over time.

We test these hypotheses by means of questionnaire responses from international fund managers and FX dealers.

\section{Data}

The analyses performed here are based on a survey questionnaire which has been used in part and described for other research (Gehrig and Menkhoff, 2003). This survey basically addresses all investment management companies in Germany managing international securities, and all FX trading banks in Germany and in Austria. The survey was preceded by intensive interviewing and by a pre-test. To improve the response rate, all respondents were promised an interpretation of the survey results. For the group of banks, support from a respective bank association was received, and there was a second mailing together with repeated telephone calls. 
The efforts described have led to comparatively high response rates of 32.2 per cent for fund managers and 68.7 per cent for FX dealers. The response rates of institutions are even higher, for example every second fund management company sent back at least one questionnaire. More information on this survey as well as on the similarly conceptualized survey from the year 1992 is given in Table 2.

The good response rate, comments from telephone conversations and some cross-checks of the data, such as the relation between position and age or the share of senior respondents for both groups examined, indicate reliable information. A comparison of our data on FX dealers with earlier survey studies (e.g. Taylor and Allen, 1992; Cheung, Chinn and Marsh, 2000) shows quite stable structures over time and for different countries. In terms of fund managers in Germany, there is information on the related field of equity management in a September 2000 survey by the Deutsche Bundesbank with 278 respondents. The directly comparable items of median age and the share of respondents with university education are almost exactly the same as in our smaller sample (see Arnswald, 2001, p.46, p.54). ${ }^{4}$ We thus conclude that the information obtained from the survey questionnaire is reliable and largely representative for our purposes.

Some descriptive statistics on the institutional situation of the respondents are given in Annex 1. More than 60 per cent of the fund managers are between 31 and 40 years old. More than 65 per cent have obtained a university degree and $79 \%$ of respondents hold a junior position. The endurance to hold onto loss-making positions is usually at least a few weeks for 80 per cent of the questionnaire participants. Finally, international assets under management of the respective company are higher

\footnotetext{
${ }^{4}$ Please note that our survey addresses only those fund managers who can decide on taking foreign exchange positions. This is often a very small number even in large asset management companies. The reason for this is the widely used overlay management of foreign exchange risk, i.e. the separation of currency risk from other allocation issues.
} 
than EUR $1 \mathrm{bn}$ for 57 per cent of managers. These figures are in some respects different from those for FX dealers (see also Annex 1). A very obvious fact is that dealers usually have a vocational training but no university education. Another striking feature is the clearly longer endurance of fund managers in holding onto loss makingpositions. However, this difference merely reflects rational anticipation of the incentive structure, and is thus seen as an institutional characteristic, and less so as an element of individual behaviour.

Comparing the institutional situation of respondents in 2001 with the response from the earlier 1992 survey reveals a high degree of stability. It is certainly the case that company sizes as given by respondents to our survey have more or less doubled, largely because of the growth in market volumes. ${ }^{5}$ This increase is not directly reflected in the number of market participants, however. FX trading has been a business with rapidly shrinking margins and strong concentration tendencies, which is why we were only able to address about half as many trading desks than nine years earlier. By contrast, the number of fund management companies and even more, the number of funds managed, increased clearly during the same time period. It therefore seems to be down to these industries' divergence as to why respondents in fund management are now younger, and FX dealers older, with the consequence that the former differences between both groups in this respect have disappeared. Note that this change in the age structure may effect compensation schemes, since younger managers can be rewarded more easily with career prospects. Hence, to the extent that career motives affect their trading behaviour, one might hypothesize that fund

\footnotetext{
${ }^{5}$ The increase is about 100 per cent for FX dealing and fund management each, assuming that companies lie exactly in the middle of each category. As the highest category is just EUR 5bn and more (turnover per day or foreign currency assets under management), a more exact comparison between both surveys is particularly difficult.
} 
managers have become increasingly more affected by economic fundamentals over time.

Overall, it can be concluded that the quality of the survey response, comparisons with other data and comparison with an earlier survey of similar design, all indicate a useful data set to be analyzed in the next section.

\section{$4 \quad$ Results}

This section reports our test results based on the questionnaire response. Hypothesis 1 relates fund managers in comparison to FX dealers with a stronger reliance on fundamental analysis at each horizon. The question on individual forecasting horizons gives a clear result, as fund managers "think" in horizons of up to a couple of weeks or even months. By contrast, FX dealers are quite short-term oriented, and take into account influences of the next few days, but rarely weeks. The responses of both groups differ significantly as can be seen in Table 3 .

Other studies inform us that fund managers - in general - rely significantly more on fundamentals than FX dealers (see Menkhoff, 1998; Gehrig and Menkhoff, 2003). Table 3 shows in more detail that the difference is less so when we compare fundamentals at a general level, since 91 per cent of fund managers but also 84 per cent of FX dealers ascribe a considerable relative importance of 20 per cent and more to fundamentals. The difference emerges when we compare the intensity with which different instruments are used. More than 60 per cent of fund managers assign fundamentals a relative importance of at least 40 per cent, but this is the case for less than 30 per cent of FX dealers. Note also that complementary results apply to technical analysis and flow analysis, which are favoured more by FX dealers. A rank 
correlation between horizon and the use of fundamentals shows, moreover, that the respective coefficient is positive for both groups.

It can be suspected that there are logical relations between the variables considered here, in particular between field ( $F X$ dealers versus fund managers), horizon (from intra-day to more than twelve months) and information type (fundamentals, charts or flows). Whereas earlier studies often focus on differences between preferred users of fundamentals - in short: fundamentalists - versus others, our attention is on the field where professionals work. Considering the strong and different incentives that impact FX dealers and fund managers, we argue that the field heavily influences the horizon, which in turn largely determines the preferred type of information. Being a fundamentalist in this sense is not so much an exogenous fact, but a decision endogenously caused by the field of work.

To analyze possible relations between the variables discussed so far in Table 3, a rank correlation matrix (not shown here) reveals that the use of fundamentals is indeed positively correlated with horizon and somewhat less with field of work. Applying stepwise regressions in explaining the use of fundamentals by considering all variables introduced so far (not shown here), leads to a clear result given at the bottom of Table 3. It is only horizon and, as a second factor, the field of work, that have the expected "explanatory" power. The interpretation of causality is problematic from a methodological viewpoint. In our case, however, is seems to be quite obvious that the field of work provides the exogenous restriction. We conclude that hypothesis 1 is partially supported by the data.

To test hypothesis 1 in more detail, we ask professionals about their forecasting horizon when opening a position. We relate professionals' replies on their forecasting horizon to the relative importance assigned to either fundamental, technical or flow 
analysis. The approach of Taylor and Allen (1992) for London chief FX dealers is thus extended to fund managers. The left part in Figure 1 presents the result for fund managers. Fundamental analysis is the most important type of information for preferred forecasting horizons of months only. At shorter horizons, fundamentals do not play the major role, and technical analysis and flow analysis predominate. This shorter horizons are of particular importance, however, as 60 per cent of fund managers focus primarily on horizons in the range of days and weeks. It thus seems justified to cautiously conclude that most decisions of this group are not strictly dominated by fundamental analysis.

Due to this unexpected result, the comparison of findings with FX dealers may be of particular importance. The result presented in the right part of Figure 1 reveals an even stronger picture for FX dealers, neatly fitting the stylized fact first advanced by Taylor and Allen (1992).

Our key finding is the observation that fund managers and FX dealers differ mostly in their respective horizons. At identical horizons, there is just a slightly more intensive use of fundamentals by fund managers, which renders weak support for hypothesis 1 only. Moreover, although fund managers rely much more heavily on fundamentals than FX dealers, they certainly do not behave like fundamentalists. It is thus an open question whether their self-rated preference for fundamental analysis is clearly related to a certain view of market imperfections and a certain preference of information sources. Hypotheses 2 and 3 state that such a relation exists.

Table 4 reports views on possible market imperfections. The first statement refers to the standard interpretation of technical analysis as a self-fulfilling prophecy. Fund managers do not agree with this motivation as a reason for using technical analysis. Thus, they do not only regard this non-fundamental analysis less than FX 
dealers but they also do not regard it as an instrument to produce coordinated behaviour and thus to herd with the market. The second statement aims at the motivation for using flow analysis. From the viewpoint of efficient markets, prices are influenced by fundamental news and not by liquidity shocks. It is thus surprising that fund managers substantially agree with the notion of relevant price influence by large market participants. Comparatively clear, although surprising again, is the answer on the relative importance of psychology to fundamentals. Fund managers strongly favour the importance of psychology. Own currency positions are seen as a distorting influence on decision-making, although to a lesser degree according to statement 4 . Finally, the median time period needed for fundamentals to succeed sometimes in the market is not instantaneously or within a very short time period, but in the category of two to six months. Summarizing these responses from a comparative viewpoint, fund managers hold views about market imperfections that tentatively better fit market efficiency than is the case for FX dealers, thus supporting hypothesis 2. However, assessing the absolute level of answers, there is a tendency not to believe in fundamentally efficient foreign exchange markets.

In another set of questions, the target groups were asked to evaluate the importance of various sources of information. Based on hypothesis 3 , it would be expected that fundamentally oriented participants prefer research produced in-house as a general source of relevant information advantage. Thereafter, externally published research as well as other available fundamental information, particularly money market rates, would be expected to be of importance. The role of stock market prices does not belong to the traditional set of exchange rate fundamentals, but has recently been claimed to be a price determinant (Hau and Rey, 2002). By contrast, talks with 
other participants may provide information about flows or views and are thus not a typical source of information for fundamentalists.

Our questionnaire replies tend to confirm these expectations as can be seen from Table 5. Indeed, research produced in-house is awarded the highest average degree of importance by fund managers. Moreover, FX dealers rate this kind of information to a lower extent, indicating that there is a difference in behaviour between both groups under investigation. A similar result applies to the level of money market rates.

Both groups do not respond differently as regards externally published exchange rate analyses and changes in stock market prices. These sources of information receive a cautious degree of importance. The picture turns again when we consider the role of direct (telephone) talks with other market participants. This is where fund managers voice their lowest interest, whereas FX dealers give their strongest commitment here - out of the five sources of information considered. Thus, fund managers do not really behave as pure fundamentalists, but fit much better with the notion of fundamentalists than FX dealers, just as stated in hypothesis 3 .

The overall picture of the responses to our survey is somewhat ambivalent. On the one hand, fund managers clearly reveal more fundamentalist-like views on market imperfections and sources of information for their decision-making, confirming hypotheses 2 and 3 . On the other hand, the level of support for theoretically expected positions of fundamentalists is not borne out. In many respects, fund managers exhibit an unexpectedly high degree of resemblance with FX dealers. This result seems to suggest that fund managers may be compensated on horizons which are comparatively short relative to fundamentals. 
Based on this evidence, we might conjecture that growth in the share of fund managers will thus definitely increase horizons and the relative importance of fundamentals in decision-making in foreign exchange markets. Related to this, most imperfections seen by FX dealers matter less, and fundamental determinants influence decision-making more. However, despite these differences, the overall approach towards fundamentals does not appear to revolutionize what we have learned from microstructure research about FX dealers. Does this gradual change justify the introduction of heterogeneous agents as fund managers and FX dealers, instead of fundamentalists and chartists? Are the findings for fund managers stable over time? These questions will be addressed in the next section.

\section{$5 \quad$ Robustness}

This section aims to check whether the findings about fund managers are robust against another preferred cut of the data (hypothesis 4), and against possible changes over time (hypothesis 5). Therefore, in a first step, the importance of the distinction into fundamentalists and non-fundamentalists (in particular chartists) is examined by cutting the data into these two groups, and recalculating the Tables 4 to 7 given above. Results are then compared with the earlier findings.

Fundamentalists are defined as those respondents who, first, give fundamentals a higher relative importance than technical analysis and flows respectively, and second, attach fundamentals a relative importance of at least 40 per cent. According to this definition, 29.1 per cent of respondents are classified as fundamentalists, and a surprising 51.7 per cent of fund managers, but only 20 per cent of FX dealers.

We find a clear pattern of responses without any relevant exception: whenever there is a significant difference between fund managers and FX dealers, this differ- 
ence emerges again between fundamentalists and non-fundamentalists where fundamentalists resemble fund managers. However, the field of work discriminates clearly better than the preferred use of fundamentals. To provide an example, 11.9 per cent of fundamentalists and 31.5 per cent of non-fundamentalists mark intra-day as their preferred horizon, compared with the wider difference of 0 per cent for fund managers and 35.9 per cent for FX dealers (see Table 3; results are not given here due to the clear pattern). As fund managers tend to give the sort of answer one would expect from a fundamentalist, we conclude that fund managers are the "better" fundamentalists than those professionals that are identified by a preferred use of fundamentals. Findings are thus in line with hypothesis 4 , stating that the distinction between fund managers and FX dealers is important in understanding heterogeneous actors in foreign exchange markets.

In a next step, we consider possible changes over time by examining hypothesis 5 . For this purpose, findings from the 2001 survey are compared with the conceptually similar survey from 1992. We have already discussed differences between both surveys regarding institutional characteristics in Section 3. Basically, we find a high degree of stationarity in most dimensions.

The situation is different, however, regarding forecasting horizons and preferred types of information. Here, we find significant changes pointing in the same direction, and indicating that fundamentals have lost importance during the 1990s. As an example, for the group of fund managers, the relative importance of fundamentals has decreased from 53.7 per cent to 46.2 per cent, and for FX dealers from 41.7 per cent to 32.4 per cent. Moreover, forecasting horizons of fund managers have significantly decreased over time. In 1992, about 68 per cent of respondents mark horizons of 
months but in 2001 it is only 38.6 per cent. This drastic and important change is shown in Figure 2 (more details in Annex 2).

The same tendency arises when we compare views concerning market imperfections over time. For all five views, we consistently find a decline in the fundamentalist position (see Annex 2 items 3 to 7 ). Technical analysis is less regarded only because of others, psychological influences as well as big market participants receive a higher attribution, and the speed in processing fundamentals is seen to have decreased. Finally, own currency positions are seen as less disturbing, which could indicate more professional decision-making or greater overconfidence (in the sense of less sensitivity towards own restrictions). It has become obvious that hypothesis 5 , stating constancy over time, is rejected by the data.

In summary, fund managers better fit the theoretical expectation of a fundamentalist than those preferring fundamentals. However, even fund managers - as fundamentalists - appear to be increasingly attracted by a shorter-term nonfundamentalist-like behaviour.

\section{Conclusions}

Fund managers are increasingly dominating foreign exchange markets. Market microstructure research indicates that the behaviour of this group could be of particular importance in understanding short-term exchange rate movements. Thus there is ample reason to examine the behaviour, characteristics and views of international fund managers regarding foreign exchange markets. This paper provides such information, based on a questionnaire survey sent to fund managers and FX dealers in Germany and Austria in 2001. 
We find that fund managers indeed differ quite substantially from FX dealers. It is therefore useful to develop models with heterogeneous agents along this line. One can expect marked changes in foreign exchange markets from the rise of fund managers. Generally speaking, fund managers fit the notion of long-term oriented fundamentalists much better than FX dealers. Despite this clear and undisputable difference between both groups, the detailed testing of five hypotheses reveals that fund managers behave only in a fundamentally oriented way when compared with FX dealers. In a rigorous way, however, fund managers cannot be identified as a truly fundamentally oriented investors. Moreover, their answers diverge increasingly over time from a true fundamental orientation, resembling ever more the short-term FX dealers' style. Their investment horizons seem to shrink and they increasingly tend to learn from order flow. The rise of fund managers will thus most likely not have any significant novel impact on information aggregation in foreign exchange markets and thus on efficiency of these markets.

The implications of these findings for policy-makers are ambiguous as before (see Willett, 2000). While market failures have to be expected, the behaviour of fund managers on foreign exchange markets is not completely alien to a fundamentalist role-model. Moreover, while also policy failure is likely to occur, straight interventions do not emerge as an immediate policy implication. Nevertheless, our findings pinpoint areas where market outcomes could be improved, in principle: First, short-term horizons are likely causes of imperfection and one would like to know how competition in fund management could be designed to increase the horizon of responsible actors. Interestingly, the often favoured tax on foreign exchange transactions, the Tobin tax, does not solve the problem as its preferred small size of for example 0.1 per cent is too small to influence fund managers decisions (Eichengreen, Tobin and Wyplosz, 
1995). Second, non-fundamental orientation of fund managers may reflect the activities of noise traders but may also be a consequence of herding behaviour. As even not fully rational noise traders may exist in the market for longer time periods (Shleifer, 2000), rational herding must be taken seriously. The only remedy seems to be performance oriented longer-term competition among fund managers, so that those who follow the herd must tentatively reveal their sub-standard performance. Third, regarding behavioural distortions in decision making one can hope that perception of this fact and the resulting incentive to improve behaviour may produce appropriate efforts. These reactions can contribute to further reduce suboptimal behaviour as there are indications that fund managers already nowadays behave more rational than individual investors (see Shiller and Pound, 1989; Shapira and Venezia, 2001).

In summary, the rise of fund managers in foreign exchange tends to improve the importance of fundamentals versus non-fundamental information. However, this will affect exchange rates only in a minor way, since their behaviour (as well as the behaviour of $\mathrm{FX}$ dealers) seems to increasingly deviate from fundamentalist positions. So the net effect on an increase in fundamental valuation may be rather small, if not negative. Moreover, fund managers' decision-making differs clearly from the theoretical notions of fundamentally oriented behaviour. One has thus to face the possibility that foreign exchange market outcomes may be suboptimal from a macroeconomic point of view, as they sometimes were in the past. If such situations of "too much" or "too late" exchange rate changes occur (Willett, 2000), policy may want to decide to directly influence market outcomes. 


\section{References}

Arnswald, T. (2001), 'Investment Behaviour of German Equity Fund Managers, An Exploratory Analysis of Survey Data', Deutsche Bundesbank Discussion Paper 08/01.

Barberis, N. and R.H. Thaler (2003), 'A Survey of Behavioral Finance', in: G.M. Constantinidis, M. Harris and R.M. Stulz (eds.), Handbook of the Economics of Finance, Vol.1B (Amsterdam et al.: Elsevier).

Bikhchandani, S. and S. Sharma (2001), 'Herd Behavior in Financial Markets: A Review', IMF Staff Papers, 47, 3, 279-310.

BIS [Bank for International Settlements](1990), Survey of Foreign Exchange Market Activity (Basel).

BIS (2002), Triennial Central Bank Survey of Foreign Exchange and Derivatives Market Activity 2001 (Basel).

Blinder, A.S. (2000), 'Central-Bank Credibility: Why Do We Care? How Do We Build It?', American Economic Review, 90, 5, 1421-1431.

Calvo, G.A. and E.G. Mendoza (2000), Rational Contagion and the Globalization of Securities Markets, Journal of International Economics, 51, 1, 79-113.

Carpenter, A. and J. Wang (2003), 'Sources of Private Information in FX Trading', Working Paper, University of New South Wales, Australia.

Cheung, Y.-W., M.D. Chinn and I.W. Marsh (2000), 'How Do UK-based Foreign Exchange Dealers Think Their Market Operates?', NBER Working Paper, No.7524.

Chevalier, J. and G. Ellison (1997), 'Risk Taking by Mutual Fund Managers as a Response to Incentives', Journal of Political Economy, 105, 6, 1167-1200. 
Clarida, R.H., L. Sarno, M.P. Taylor and G. Valente (2003), 'The Out-of-Sample Success of Term Structure Models as Exchange Rate Predictors: A Step beyond', Journal of International Economics, 60, 1, 61-83.

Cooper, R.N. (1999), 'Key Currencies after the Euro', The World Economy, 22, 1, 123.

De Grauwe, P. (2000), 'Exchange Rates in Search of Fundamentals: The Case of the Euro-Dollar Rate', International Finance, 3, 3, 329-356.

Dow, J. and G. Gorton (1997), 'Noise Trading, Delegated Portfolio Management, and Economic Welfare', Journal of Political Economy, 105, 1024-1050.

Eichengreen, B., J. Tobin and C. Wyplosz (1995), Two Cases for Throwing Sand in the Wheels of International Finance, Economic Journal, 105, 428, $162-$ 172.

Evans, M.D.D. and R.K. Lyons (2002), 'Order Flow and Exchange Rate Dynamics,' Journal of Political Economy, 110, 1, 170-180.

Frankel, J.A. and K.A. Froot (1990), 'Chartists, Fundamentalists and Trading in the Foreign Exchange Market', American Economic Review, 80, 2, 181-185.

Frankel, J.A. and A.K. Rose (1995), 'Empirical Research on Nominal Exchange Rates', in: G. Grossmann and K. Rogoff (eds.), Handbook of International Economics, Vol.III (Amsterdam et al.: North-Holland), 1689-1729.

Gehrig, T. and L. Menkhoff (2003), 'Extended Evidence on the Use of Technical Analysis in Foreign Exchange', International Journal of Finance and Economics, forthcoming.

Goodhart, C. (1988), 'The Foreign Exchange Market: A Random Walk with a Dragging Anchor', Economica, 55, 220, 437-460. 
Griffin, J.M., S. Ji and J.S. Martin (2003), 'Momentum Investing and Business Cycle Risk: Evidence from Pole to Pole', Journal of Finance, 58, 6, 2515-1547.

Hau, H. and H. Rey (2002), 'Exchange Rates, Equity Prices and Capital Flows', Working Paper (INSEAD).

Howitt, P. (2002), 'Looking Inside the Labor Market: A Review Article', Journal of Economic Literature, 40, 1, 125-138.

Kahneman, D., J.L. Knetsch and R.H. Thaler (1991), 'Anomalies: The Endowment Effect, Loss Aversion, and Status Quo Bias', Journal of Economic Perspectives, 5, 1, 193-206.

Lyons, R.K. (1995), 'Tests of Microstructural Hypotheses in the Foreign Exchange Market', Journal of Financial Economics, 39, 2-3, 321-351.

Lyons, R.K. (2001), The Microstructure Approach to Exchange Rates (Cambridge: MIT Press).

MacDonald, R. (1999), 'Exchange Rate Behaviour: Are Fundamentals Important?', Economic Journal, 109, 459, 673-691.

Mende, A., L. Menkhoff and C. Osler (2004), 'The Cross-Sectional Structure of Currency Spreads: A Story of Market Power and Strategic Dealing', Discussion Paper (University of Hannover).

Menkhoff, L. (1998), 'The Noise Trading Approach - Questionnaire Evidence from Foreign Exchange', Journal of International Money and Finance, 17, 3, 547-564.

Neely, C.J. and L. Sarno (2002), 'How Well Do Monetary Fundamentals Forecast Foreign Exchange Rates?', Federal Reserve Bank of St. Louis Review, 84, 5, 51-74. 
Rogoff, K. (1996), 'The Purchasing Power Parity Puzzle', Journal of Economic Literature, 34, 2, 647-668.

Sarno, L. and M.P. Taylor (2002), The Economics of Exchange Rates (Cambridge et al.: Cambridge University Press).

Shapira, Z. and I. Venezia (2001), 'Patterns of Behaviour of Professionally Managed and Independent Investors', Journal of Banking and Finance, 25, 8, 15731587.

Shefrin, H. (2002), Beyond Greed and Fear: Understanding Behavioral Finance and the Psychology of Investing (New York: Oxford University Press).

Shiller, R.J. (1989), Market Volatility (Cambridge Mass.: MIT Press).

Shiller, R.J., F. Kon-Ya and Y. Tsutsui (1996), 'Why Did the Nikkei Crash? Expanding the Scope of Expectations Data Collection', Review of Economics and Statistics, 78, 1, 156-164.

Shiller, R.J. and J. Pound (1989), 'Survey Evidence on Diffusion of Interest and Information among Investors', Journal of Economic Behavior and Organization, 12, 1, 47-66.

Shleifer, A. (2000), Clarendon Lectures: Inefficient Markets (Oxford et al.: Oxford University Press).

Sias, R.W. (2004), 'Institutional Herding', Review of Financial Studies, 17, 1, 165-206.

Strong, N. and X. Xu (2003), 'Understanding the Equity Home Bias: Evidence from Survey Data', Review of Economics and Statistics, 85, 2, 307-312.

Tavlas, G.S. (2003), 'The Economics of Exchange-Rate Regimes: A Review Essay', The World Economy, 26, 8, 1215-1246.

Taylor, M.P. (1995), 'The Economics of Exchange Rates', Journal of Economic Literature, 33, 1, 13-47. 
Taylor, M.P. and H. Allen (1992), 'The Use of Technical Analysis in the Foreign Exchange Market', Journal of International Money and Finance, 11, 3, 304314.

Willett, T.D. (1998), 'Credibility and Discipline Effects of Exchange Rates as Nominal Anchors: The Need to Distinguish Temporary from Permanent Pegs', The World Economy, 21, 6, 803-826.

Willett, T.D. (2000), International Financial Markets as Sources of Crises or Discipline: The too Much, too Late Hypothesis, Essays in International Finance No.218 (Princeton University). 
TABLE 1. The share of counterparties in the FX market from 1989 to 2001

\begin{tabular}{lccccc}
\hline Counterparties & 1989 & 1992 & 1995 & 1998 & 2001 \\
Fund managers & n.a. & $12 \%$ & $20 \%$ & $19 \%$ & $28 \%$ \\
FX dealers & $79 \%$ & $70 \%$ & $64 \%$ & $64 \%$ & $59 \%$ \\
Corporations & $21 \%$ & $18 \%$ & $16 \%$ & $17 \%$ & $13 \%$ \\
$\begin{array}{l}\text { Total daily turnover } \\
\text { (in bn. USD) }\end{array}$ & 590 & 820 & 1,190 & 1,490 & 1,200 \\
\hline
\end{tabular}

Sources: Percentage figures are from BIS (1990), Table A-1 for 1989 and from BIS (2002), Table B.3 for the remaining years. The turnover information is from BIS (2002), Table B.1 and covers somewhat more business than incorporated in the percentage figures. The exact BIS terminology on counterparties is "reporting dealers" for FX dealers, "other financial institutions" for fund managers (fund managers are the major group here according to BIS, 2002, p.7) and "non-financial customers" for corporations.

TABLE 2. Information on the survey responses

\begin{tabular}{lrcrc}
\hline Groups & \multicolumn{2}{c}{ 2001-survey } & \multicolumn{2}{c}{ 1992-survey } \\
addressed & response & response rate & response & response rate \\
Fund managers & 58 & $32.2 \%$ & 51 & $36.7 \%$ \\
FX dealers & 145 & $68.7 \%$ & 153 & $41.9 \%$ \\
& & & & \\
Total & 203 & & 204 & \\
\hline
\end{tabular}




\section{TABLE 3. Forecasting horizons and kinds of information}

Question: "How far in advance do you take into account possible influences on the exchange rates when opening a position? Please, only one answer:" [1: intra-day, ..., 6:> 12 months]

Question: "Please evaluate the importance of the three following information types for your typical decision making, by distributing a total of 100 points. For information types which you do not use, please give 0 points."

... Fundamentals (economic, political)

... Technical analysis (charts, quantitative methods)

... $\quad$ Flows (who is doing what, which customer orders are existing)

\begin{tabular}{|c|c|c|c|c|}
\hline \multirow[t]{2}{*}{ Question } & \multirow[t]{2}{*}{ Response category } & \multicolumn{2}{|c|}{ Distribution of responses } & \multirow{2}{*}{$\begin{array}{l}\mathrm{H}_{0}: \text { No } \\
\text { difference }\end{array}$} \\
\hline & & $\begin{array}{c}\text { Fund } \\
\text { managers }\end{array}$ & FX dealers & \\
\hline \multirow[t]{7}{*}{ Horizon } & intra-day & $0.0 \%$ & $35.9 \%$ & \multirow{7}{*}{$\begin{array}{l}-7.545^{\star * *} \\
{[0.000]}\end{array}$} \\
\hline & few days & $24.6 \%$ & $42.1 \%$ & \\
\hline & few weeks & $36.8 \%$ & $15.9 \%$ & \\
\hline & 2-6 months & $33.3 \%$ & $4.1 \%$ & \\
\hline & 6-12 months & $5.3 \%$ & $0.7 \%$ & \\
\hline & >12 months & $0.0 \%$ & $1.4 \%$ & \\
\hline & $\mathrm{n}$ & 57 & 145 & \\
\hline \multirow{8}{*}{$\begin{array}{l}\text { Information } \\
\text { type }\end{array}$} & fundamentals mean & $46.2 \%$ & $32.4 \%$ & \multirow{5}{*}{$\begin{array}{l}-4.108^{\star \star \star x} \\
{[0.000]}\end{array}$} \\
\hline & fund. $\geq 20 \%$ & $91.2 \%$ & $84.0 \%$ & \\
\hline & fund. $\geq 30 \%$ & $82.5 \%$ & $63.2 \%$ & \\
\hline & fund. $\geq 40 \%$ & $61.4 \%$ & $28.2 \%$ & \\
\hline & fund. $\geq 50 \%$ & $50.9 \%$ & $20.1 \%$ & \\
\hline & technical analysis mean & $37.0 \%$ & $41.4 \%$ & \multirow{3}{*}{$\begin{array}{l}-1.696^{*} \\
{[0.090]} \\
-3.080^{* * *} \\
{[0.002]}\end{array}$} \\
\hline & flows mean & $16.8 \%$ & $26.2 \%$ & \\
\hline & $\mathrm{n}$ & 57 & 144 & \\
\hline \multicolumn{2}{|c|}{$\begin{array}{l}\text { Rank correlation of horizon with funda- } \\
\text { mentals (points) }\end{array}$} & $\begin{array}{c}0.421^{* \star \star} \\
(0.001) \\
{[56]}\end{array}$ & $\begin{array}{c}0.066 \\
(0.435) \\
{[144]}\end{array}$ & \\
\hline
\end{tabular}

Regression explaining the intensity of using fundamentals by two determinants, i.e. horizon and being a fund manager (value of 1 , but value of 0 for FX dealers):

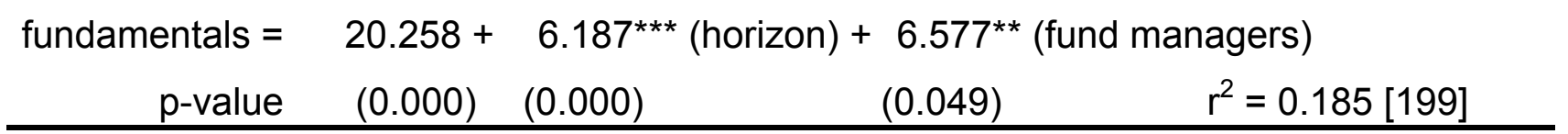

Significance ( $p$-value) in parenthesis

Number of responses in squared brackets

Stars refer to level of significance, ${ }^{*}: 10$ per cent, ${ }^{* *}: 5$ per cent. ${ }^{* * *}: 1$ per cent 


\section{FIGURE 1. The relative importance of fundamentals at preferred forecasting horizons}

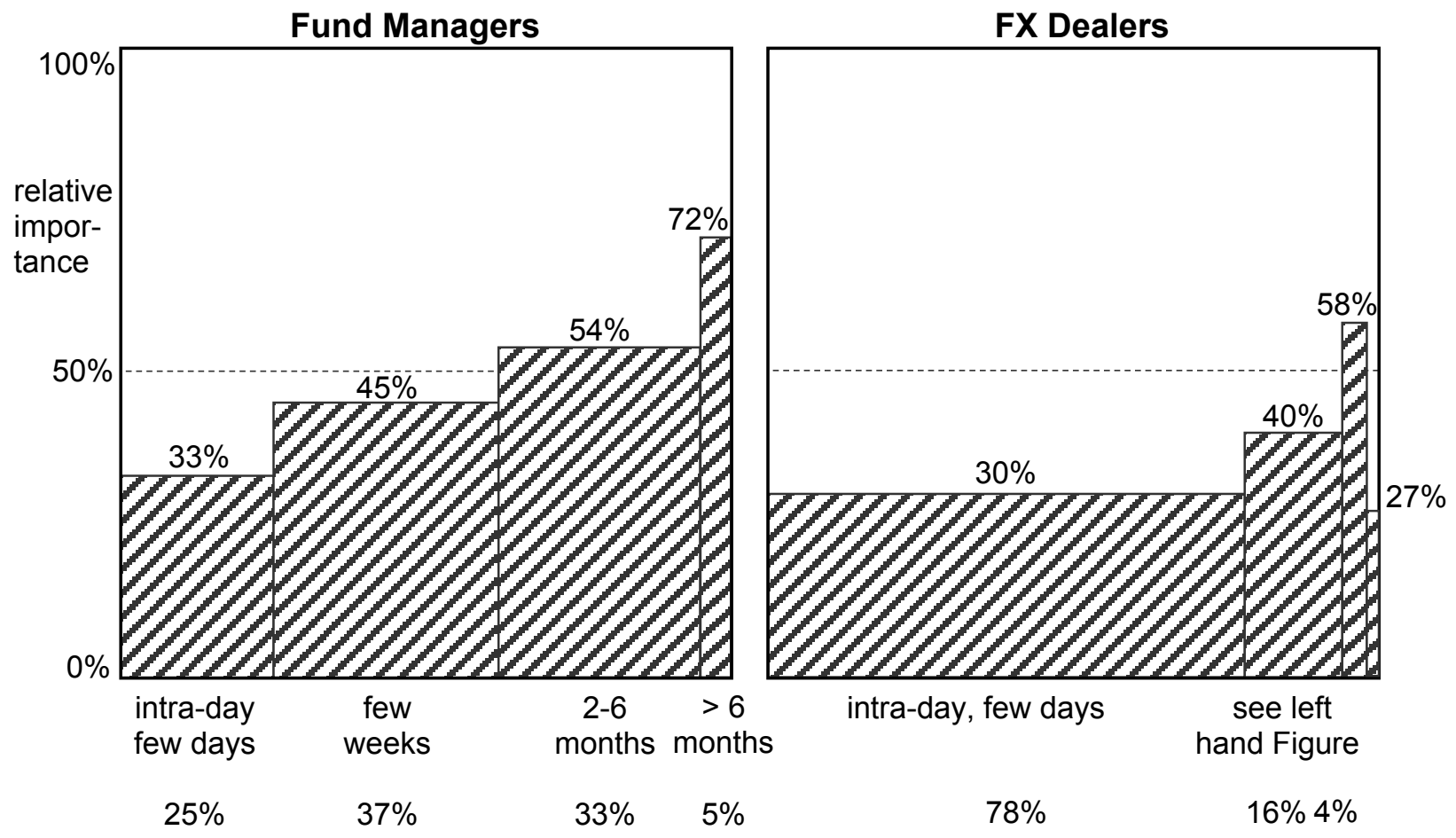

Note: Please read the first value of $33 \%$ as follows: when asked for their forecasting horizof, $25 \%$ of reporting fund managers mention horizons of "intra-day" or "few days". This group gives fundamentals a relative importance in their typical decision making of $33 \%$ (see Table 3 for exact questions and response items). 


\section{TABLE 4. Views about market imperfections}

Question: "What is in your opinion the value of technical analysis?"

( ) I regard technical analysis only because others regard it.

Question: "Do you believe that big market participants have an influence on price formations?" ( ) Yes, they can "make" exchange rates for a while via own position taking and customer orders.

Question: "How much importance do fundamentals and psychology have for exchange rate movements?"

( ) People are not machines; thus psychology is clearly more important than fundamentals.

Question: "Do you think your decisions are influenced by the currency position you hold at any particular moment?"

( ) The positions taken bring emotions into the decision-making process, thereby damaging the latter.

Question: "How long does it sometimes need that fundamentals succeed in foreign exchange markets?"

\begin{tabular}{|c|c|c|c|c|}
\hline Statement & $\begin{array}{l}\text { Response } \\
\text { category }^{(1)}\end{array}$ & $\begin{array}{l}\text { Mean }^{(1)} \text { or distri } \\
\text { sponses res }\end{array}$ & $\begin{array}{l}\text { Jution of re- } \\
\text { ectively }\end{array}$ & $\begin{array}{c}\mathrm{H}_{0}: \mathrm{No} \\
\text { difference }\end{array}$ \\
\hline Regard technical & average & 3.59 & 3.12 & $-2.148^{\star \star x}$ \\
\hline $\begin{array}{l}\text { analysis because } \\
\text { of others }\end{array}$ & $\mathrm{n}$ & 58 & 141 & {$[0.032]$} \\
\hline Big market par- & average & 2.88 & 1.94 & $-5.062^{* k *}$ \\
\hline $\begin{array}{l}\text { ticipants influence } \\
\text { prices }\end{array}$ & $\mathrm{n}$ & 58 & 145 & {$[0.000]$} \\
\hline Higher impor- & average & 2.78 & 2.28 & $-2.703^{* * *}$ \\
\hline $\begin{array}{l}\text { tance of psycho- } \\
\text { logical influences }\end{array}$ & $\mathrm{n}$ & 58 & 144 & {$[0.007]$} \\
\hline Own currency & average & $3.70^{\circ}$ & 2.83 & $-3.824^{* k \star}$ \\
\hline position matters & $\mathrm{n}$ & 56 & 138 & {$[0.000]$} \\
\hline Fast processing & intra-day & $7.0 \%$ & $11.9 \%$ & $-2.896^{* * *}$ \\
\hline fundamentals & few days & $12.3 \%$ & $18.5 \%$ & [0.004] \\
\hline & $\begin{array}{l}\text { few weeks } \\
2-6 \text { months }\end{array}$ & $\begin{array}{l}14.0 \% \\
24.6 \%\end{array}$ & $\begin{array}{l}24.4 \% \\
15.6 \%\end{array}$ & {$[0.004]$} \\
\hline & $6-12$ months & $10.5 \%$ & $20.7 \%$ & \\
\hline & $>12$ months & $31.6 \%$ & $8.9 \%$ & \\
\hline & $\mathrm{n}$ & 58 & 143 & \\
\hline
\end{tabular}

(1) There are six response categories, ranging from 1 for "full agreement" to 6 for "full disagreement". Thus, a mean of 3.5 or less indicates rather agreement with the statement.

(2) $\mathrm{H}_{0}$ states that there is no difference in response between the groups of fund managers and $\mathrm{FX}$ dealers. The figures given are the z-value of the Mann-Whitney U-test and the $p$-value in squared brackets. 
TABLE 5. The importance of different sources of information

Question: "How important are for your decision-making the following sources of information? Please, evaluate its importance with a number from 1 to 6:"

\begin{tabular}{|c|c|c|c|c|}
\hline Question & $\begin{array}{l}\text { Response } \\
\text { categorv }\end{array}$ & $\begin{array}{r}\text { Distribution o } \\
\text { Fund managers }\end{array}$ & $\begin{array}{l}\text { responses } \\
\text { FX dealers }\end{array}$ & $\begin{array}{c}\mathrm{H}_{0}: \mathrm{No} \\
\text { difference }\end{array}$ \\
\hline $\begin{array}{l}\text { In-house produced } \\
\text { analyses }\end{array}$ & $\begin{array}{l}\text { average } \\
\mathrm{n}\end{array}$ & $\begin{array}{r}3.16 \\
56\end{array}$ & $\begin{array}{r}3.62 \\
140\end{array}$ & $\begin{array}{l}-2.070^{* \star} \\
{[0.038]}\end{array}$ \\
\hline $\begin{array}{l}\text { Externally published } \\
\text { exchange rate } \\
\text { analyses }\end{array}$ & $\begin{array}{l}\text { average } \\
\mathrm{n}\end{array}$ & $\begin{array}{r}3.25 \\
57\end{array}$ & $\begin{array}{r}3.23 \\
141\end{array}$ & $\begin{array}{l}-0.337 \\
{[0.736]}\end{array}$ \\
\hline $\begin{array}{l}\text { Level of money mar- } \\
\text { ket rates }\end{array}$ & $\begin{array}{l}\text { average } \\
\mathrm{n}\end{array}$ & $\begin{array}{r}3.25 \\
57\end{array}$ & $\begin{array}{r}3.90 \\
138\end{array}$ & $\begin{array}{l}-2.917^{* \star \star} \\
{[0.004]}\end{array}$ \\
\hline $\begin{array}{l}\text { Changes of stock } \\
\text { market prices }\end{array}$ & $\begin{array}{l}\text { average } \\
\mathrm{n}\end{array}$ & $\begin{array}{r}3.40 \\
57\end{array}$ & $\begin{array}{r}3.55 \\
139\end{array}$ & $\begin{array}{l}-0.587 \\
{[0.557]}\end{array}$ \\
\hline $\begin{array}{l}\text { Direct (telephone) } \\
\text { talks with other mar- } \\
\text { ket participants }\end{array}$ & $\begin{array}{l}\text { average } \\
\mathrm{n}\end{array}$ & $\begin{array}{r}3.48 \\
58\end{array}$ & $\begin{array}{r}2.70 \\
143\end{array}$ & $\begin{array}{l}-3.676^{\star \star \star} \\
{[0.000]}\end{array}$ \\
\hline
\end{tabular}

${ }^{(1)} \mathrm{H}_{0}$ states that there is no difference in response between the groups of fund managers and FX dealers. The figures given are the $z$-value of the Mann-Whitney U-test and the $p$-value in squared brackets.

Figure 2. Forecasting horizons in 1992 and 2001

Fund Managers

FX Dealers 

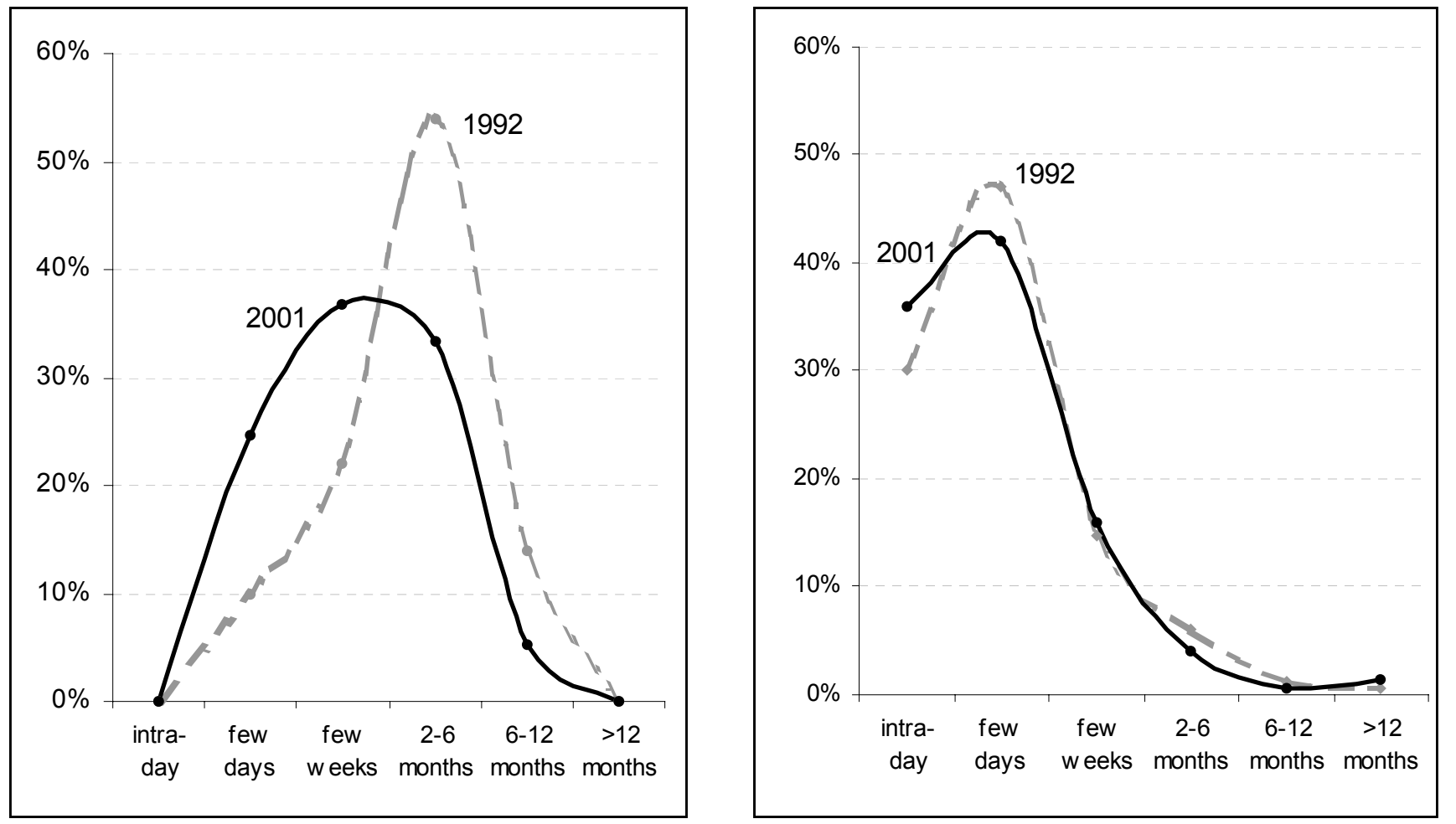

Note: For the exact underlying question see Table 3. 
ANNEX 1. The institutional situation of fund managers and FX dealers

\begin{tabular}{|c|c|c|c|c|}
\hline \multirow[t]{2}{*}{ Question } & \multirow[t]{2}{*}{ Response category } & \multicolumn{2}{|c|}{ Distribution of responses } & \multirow{2}{*}{$\begin{array}{c}\mathrm{H}_{0}: \mathrm{No} \\
\text { difference }^{(4)}\end{array}$} \\
\hline & & $\begin{array}{c}\text { Fund } \\
\text { managers }\end{array}$ & FX dealers & \\
\hline \multirow[t]{7}{*}{ Age } & $<31$ years & $19.0 \%$ & $22.8 \%$ & \multirow{7}{*}{-0.858} \\
\hline & $31-35$ years & $39.7 \%$ & $26.9 \%$ & \\
\hline & $36-40$ years & $22.4 \%$ & $23.4 \%$ & \\
\hline & $41-45$ years & $12.1 \%$ & $13.8 \%$ & \\
\hline & $46-50$ years & $5.2 \%$ & $6.2 \%$ & \\
\hline & $>50$ years & $1.7 \%$ & $6.9 \%$ & \\
\hline & $\mathrm{n}$ & 58 & 145 & \\
\hline \multirow{2}{*}{$\begin{array}{l}\text { Education }^{(1)} \\
\text { (highest degree) }\end{array}$} & vocational & $34.5 \%$ & $85.5 \%$ & \multirow{2}{*}{$\begin{array}{l}-6.817^{* * \star} \\
{[0.000]}\end{array}$} \\
\hline & university & $\begin{array}{r}65.5 \% \\
58\end{array}$ & $15.0 \%$ & \\
\hline \multirow{3}{*}{ Position } & superior & $21.1 \%$ & $29.0 \%$ & -1.141 \\
\hline & non-superior & $78.9 \%$ & $71.0 \%$ & \multirow{2}{*}{ [0.254] } \\
\hline & n & 57 & 145 & \\
\hline \multirow{7}{*}{$\begin{array}{l}\text { Endurance } \\
\text { (how long hold } \\
\text { on to loss posi- } \\
\text { tions) }\end{array}$} & intra day & $1.9 \%$ & $33.1 \%$ & \multirow{7}{*}{$\begin{array}{l}-7.663^{* * *} \\
{[0.000]}\end{array}$} \\
\hline & few days & $18.5 \%$ & $43.7 \%$ & \\
\hline & few weeks & $37.0 \%$ & $19.0 \%$ & \\
\hline & 2-6 months & $27.8 \%$ & $2.1 \%$ & \\
\hline & 6-12 months & $5.6 \%$ & $1.4 \%$ & \\
\hline & $>12$ months & $9.3 \%$ & $0.7 \%$ & \\
\hline & $\mathrm{n}$ & 54 & 142 & \\
\hline \multirow[t]{7}{*}{ Company size ${ }^{(3)}$} & $<€ 0.2 \mathrm{bn}$ & $14.3 \%$ & $15.8 \%$ & \multirow{7}{*}{$\begin{array}{l}-1.143 \\
{[0.253]}\end{array}$} \\
\hline & $€ 0.2 \mathrm{bn}-€ 0.5 \mathrm{bn}$ & $16.1 \%$ & $13.7 \%$ & \\
\hline & $€ 0.5 \mathrm{bn}-€ 1 \mathrm{bn}$ & $12.5 \%$ & $12.9 \%$ & \\
\hline & $€ 1$ bn - $€ 2$ bn & $10.7 \%$ & $23.7 \%$ & \\
\hline & $€ 2$ bn $-€ 5$ bn & $17.9 \%$ & $19.4 \%$ & \\
\hline & $>€ 5 \mathrm{bn}$ & $28.6 \%$ & $14.4 \%$ & \\
\hline & $\mathrm{n}$ & 56 & 139 & \\
\hline
\end{tabular}

(1) The category "vocational education" includes more advanced degrees, such as absolving a bank academy ("Bankakademie") etc. The category "university education" includes degrees from universities of applied sciences ("Fachhochschulen").

(2) "How long do you believe you can afford to hold on to loss positions?" Please, only one answer:" [1: intra-day, ..., 6:> 12 months]

(3) Company size is measured by the average daily FX trading turnover volume of the dealer's bank or by international funds under management of the fund manager's asset management company.

(4) The $\mathrm{H}_{0}$ hypothesis states that there is no difference in response between the groups of fund managers and FX dealers. The figure given is the z-value of the Mann-Whitney U-test, the $p$-value is in squared brackets. 
ANNEX 2. Changes over time for fund managers and FX dealers

\begin{tabular}{|c|c|c|}
\hline Finding & Fund managers & FX dealers \\
\hline Declining importance of fundamentals & $\begin{array}{l}-1.904^{*} \\
{[0.057]}\end{array}$ & $\begin{array}{l}-4.263^{* * *} \\
{[0.000]}\end{array}$ \\
\hline Shorter forecasting horizons & $\begin{array}{l}-3.112^{* * *} \\
{[0.002]}\end{array}$ & $\begin{array}{l}-0.825 \\
{[0.409]}\end{array}$ \\
\hline $\begin{array}{l}\text { Less regard of technical analysis be- } \\
\text { cause of others }\end{array}$ & $\begin{array}{l}-0.566 \\
{[0.572]}\end{array}$ & $\begin{array}{l}-3.521^{* * *} \\
{[0.000]}\end{array}$ \\
\hline $\begin{array}{l}\text { Increased higher importance of } \\
\text { psychological influences }\end{array}$ & $\begin{array}{l}-1.820^{*} \\
{[0.069]}\end{array}$ & $\begin{array}{l}-2.587^{* * *} \\
{[0.010]}\end{array}$ \\
\hline $\begin{array}{l}\text { Higher influence of big market partici- } \\
\text { pants on prices }\end{array}$ & $\begin{array}{l}-1.519 \\
{[0.129]}\end{array}$ & $\begin{array}{l}-1.290 \\
{[0.197]}\end{array}$ \\
\hline $\begin{array}{l}\text { Less disturbance from own currency } \\
\text { position }\end{array}$ & $\begin{array}{l}-2.319^{* *} \\
{[0.020]}\end{array}$ & $\begin{array}{l}-4.751^{* * \ldots} \\
{[0.000]}\end{array}$ \\
\hline $\begin{array}{l}\text { Decreased speed in processing fun- } \\
\text { damentals }\end{array}$ & $\begin{array}{l}-1.793^{*} \\
{[0.073]}\end{array}$ & $\begin{array}{l}-3.626^{\star \star \star \star} \\
{[0.000]}\end{array}$ \\
\hline
\end{tabular}

Note: This table informs whether the "findings" represent statistically significant changes over time for fund managers and FX dealers each. The $\mathrm{H}_{0}$ of no change is tested by a Mann-Whitney U-test. 